\title{
The origins of the Romance analytic passive: evidence from word order
}

\author{
Lieven Danckaert ${ }^{1}$
}

1. Introduction: passives from Latin to Romance

In Classical Latin (informally defined as the period from ca. $100 \mathrm{BC}$ to $200 \mathrm{AD}$ ), verbal inflectional paradigms consist of both synthetic and analytic forms. The latter are always a combination of a past participle and a BE-auxiliary. Passive verbs are synthetic in the socalled infectum tenses (present (1), imperfect and future tense), but analytic in the perfectum (perfect (2), pluperfect and future perfect). Exactly the same holds for (semi-)deponents (i.e. predicates with passive morphology but no passive semantics/argument structure, see e.g. Embick 2000).

\begin{tabular}{lllll} 
si non & ips-e & amic-us & per & se \\
if not & self-NOM & friend-NOM by & REFL.ACC \\
ama-tur & \multicolumn{2}{c}{ tot-o } & pector-e & \\
love-PASS.PRS.3SG & whole-ABL & heart-ABL
\end{tabular}

'if the friend himself is not wholeheartedly loved for his own sake' (Cicero, De legibus 1.49)

$\begin{array}{llll}\text { (2) Iason } \quad \text { a } & \text { Mede-a } & \text { Vener-is impulsu } \\ \text { Iason.NOM by } & \text { Medea-ABL } & \text { Venus-GEN instigation.ABL } \\ \text { amat-us } & \text { est. } & \\ \text { loved-NOM.M.SG } & \text { be.PRS.3SG } & \\ \text { 'Jason was loved by Medea at the instigation of Venus.' (Hyginus, Fabulae 22.4) }\end{array}$

In (2) there is an apparent mismatch between the tense of the auxiliary est (which in isolation is a present tense), and the tense of the entire analytic expression amatus est, which is a (perfective) past tense. As will be elaborated on shortly, from the earliest Latin texts onwards alternative perfective BE-periphrases of the type amatus fui (with a perfective auxiliary) are available, which are not characterized by this 'tense mismatch'. This innovative pattern becomes more frequent over time, in apparent competition with the older amatus est perfects. This development can be considered the first in a series of innovations that gave rise to the formation of the Romance passive voice paradigm, which is different from the (Classical) Latin one in two important respects. First, none of the Romance passive periphrases display the 'tense mismatch' just introduced. Second, all synthetic passives have been replaced by analytic expressions consisting of a past participle and one or more auxiliaries. The basic picture is summarized in Table 1, with examples from Standard Modern Italian taken to exemplify the whole of present day Romance (with obvious simplifications):

\footnotetext{
${ }^{1}$ The research reported on in this paper was funded by postdoctoral grants of the 'Bijzonder Onderzoeksfonds' (BOF) of Ghent University (grant No. BOF11/PDO/042) and of the 'Fonds voor Wetenschappelijk Onderzoek' (FWO) (grant No. FWO13/PDO/024).
} 
Table 1: Passives in Latin and Romance (indicatives).

\begin{tabular}{|l|c|c|}
\cline { 2 - 3 } \multicolumn{1}{c|}{} & (Classical) Latin & Romance (Standard Italian) \\
\hline $\begin{array}{l}\text { Present } \\
\text { (infectum) }\end{array}$ & $\begin{array}{c}\text { amor 'I am loved' } \\
\text { SYNTHETIC }\end{array}$ & $\begin{array}{c}\text { sono amato 'I am loved' } \\
\text { ANALYTIC, NO TENSE MISMATCH }\end{array}$ \\
\hline $\begin{array}{l}\text { Past } \\
\text { (perfectum) }\end{array}$ & amatus sum 'I was loved' & fui amato 'I was loved' \\
ANALYTIC, TENSE MISMATCH & ANALYTIC, NO TENSE MISMATCH \\
\hline
\end{tabular}

Here I take the Italian simple past (passato remoto, which I assume to be the direct descendant of (Late) Latin amatus fui-type periphrases) as the prototype of a Romance passive past tense, as it is clearly older than (and now often replaced by) other periphrastic structures such as sono stato amato 'I was/have been loved' (the so-called passato prossimo), of which there are no traces before $600 \mathrm{AD}$ (i.e. the period that I am concerned with here). ${ }^{2}$

In any event, there is good evidence that the change from amatus sum to fui amato (which does away with the tense mismatch, cf. the bottom row in Table 1) started very early. In contrast, the decline of synthetic passives sets in much later, analytic formations with nonperfective semantics only being attested very sporadically even in the very latest Latin texts (cf. section 2.1.2). It is commonly assumed that once the new analytic perfects (amatus fui, no tense mismatch) were firmly established, the old (amatus est, tense mismatch) perfects underwent a semantic change (from denoting past tense to present tense) and were so to speak 'recycled' as the new analytic present passives. In other words, amatus est is taken to be the source of sono amato, as the end point of a series of changes which started much earlier. The aim of this paper is to modify this picture, with key evidence coming from a number of novel observations on word order in Late Latin.

\section{The development of Latin BE-periphrases: the state of the art}

\subsection{Some background}

I will start by giving an overview of a number of developments that affected the Latin voice system, as they are documented in the textual records. I will restrict myself to those changes which are relevant to the main point at issue, viz. the ones summarized in Table 1. I will not be concerned with other Late Latin developments, such as the use of fio 'become' as a passive auxiliary, or the emergence of passive-like structures involving the reflexive pronoun se (for recent discussion of these and related issues, see Cennamo $(2001,2005)$ and Adams (2013: 674-724)).

\subsubsection{Perfectum tenses: the disappearance of the tense mismatch}

As hinted at above, some of the developments that differentiate the Classical (and actually also Archaic) Latin voice system and the corresponding Romance paradigms can be traced back to the earliest documented stages of Latin. More specifically, from Plautus (ca. 200 BC) onwards, the old amatus est periphrases, characterized by the above-mentioned tense mismatch, appear alongside apparently synonymous structures lacking this mismatch. Consider for instance the following minimal pair: the example in (3) features a (deponent)

\footnotetext{
${ }^{2}$ The full empirical landscape of (Old) Romance BE-periphrases is of course much more complicated (see Ledgeway ([1997] 1999) and Telve (2005) for relevant discussion). For one thing, many of the structures that were prevalent in Late Latin, such as future perfects (amatus fuerit) and pluperfects (amatus fuerat) do not seem to survive much later than $600 \mathrm{AD}$.
} 
future perfect with a 'simple future' auxiliary (ero, i.e. a plain future), whereas in (4) we see the perfective form fuero (a future perfect):

$\begin{array}{llll}\text { (3) donec } & \text { persecut-us } & \text { uolp-em } & \text { er-o } \\ \text { until } & \text { tracked.down-NOM.M.SG } & \text { fox-ACC } & \text { be-FUT.1SG }\end{array}$

'until I have tracked down the fox' (Plautus, Miles gloriosus 269)

(4) Si ego min-am non ult-us fu-er-o probe

if I.NOM mina-ACC not avenged-NOM.M.SG be-FUTPRF-1SG well

'if I will not have taken proper revenge for the mina (a sum of money, ld)'

(Plautus, Poenulus 1280)

In what follows, I will refer to the older structures as 'E-periphrases' and to the innovative pattern as 'F-periphrases' (cf. the first letter of (most of) the auxiliaries in the relevant structures). The basic paradigm is given in Table 2 (illustrated with passives only, but exactly the same facts hold for deponents):

Table 2: E- and F-periphrases in passives: the perfectum.

\begin{tabular}{|c|l|c|c|}
\cline { 2 - 3 } \multicolumn{1}{c|}{} & $\begin{array}{c}\text { E-periphrases (old): } \\
\text { TENSE MISMATCH }\end{array}$ & $\begin{array}{c}\text { F-periphrases (new): } \\
\text { NO TENSE MISMATCH }\end{array}$ \\
\hline \multirow{3}{*}{ Infinitive (perfect) } & amatus esse & amatus fuisse \\
\hline \multirow{3}{*}{ Indicative } & perfect & amatus sum & amatus fui \\
\cline { 2 - 4 } & pluperfect & amatus eram & amatus fueram \\
\cline { 2 - 4 } & future perfect & amatus ero & amatus fuero \\
\hline \multirow{2}{*}{ Subjunctive } & perfect & amatus sim & amatus fuerim \\
\cline { 2 - 4 } & pluperfect & amatus essem & amatus fuissem \\
\hline
\end{tabular}

The development from E to F-periphrases is discussed in among others Leumann (1921), Haverling (2008, 2010), de Melo (2012) and Danckaert (2016). As detailed in Danckaert (2016), throughout the lifespan of the Latin language, F-periphrases are the overall minority pattern, but they can be shown to gain ground in the course of time. In certain environments (especially future perfects, and to a lesser extent pluperfects), Late Latin F-periphrases even outnumber their E-counterparts.

\subsubsection{Infectum tenses: from synthetic to analytic}

It is widely accepted that the changes affecting the infectum tenses take place later than the shift from E to F in the perfectum (for general discussion, see Muller (1924), Herman (2002) and de Melo (2012)). The data summarized in Table 3 show a new set of BE-periphrases (rightmost column), which are apparently formally identical to the old E-periphrases in the perfectum (cf. the E-paradigm in Table 2). 
Table 3: Passives in the infectum.

\begin{tabular}{|c|c|c|c|}
\hline & & $\begin{array}{c}\text { SYNTHETIC } \\
\text { (old) }\end{array}$ & $\begin{array}{l}\text { ANALYTIC, NO TENSE } \\
\text { MISMATCH (new) }\end{array}$ \\
\hline \multicolumn{2}{|c|}{ Infinitive (perfect) } & amari & amatus esse \\
\hline \multirow{3}{*}{ Indicative } & perfect & amor & amatus sum \\
\hline & pluperfect & amabar & amatus eram \\
\hline & future perfect & amabor & amatus ero \\
\hline \multirow{2}{*}{ Subjunctive } & perfect & amer & amatus sim \\
\hline & pluperfect & amarer & amatus essem \\
\hline
\end{tabular}

It needs to be added that most of the forms in the rightmost column of Table 3 are actually hypothetical, as they are not attested as such in any Latin text. Only a few convincing examples of clearly verbal (i.e. non-adjectival) BE-periphrases which do not express any notion of perfectivity or temporal anteriority can be found (Väänänen 1981'3 : 130; de Melo 2012). One of the earliest attestations is from Egeria's Itinerarium (written around 385 AD):

$\begin{array}{llllll}\text { [...] tant-us } & \text { rugitu-s } & \text { et mugitu-s } & \text { tot-ius } & \text { popul-i } \\ \text { so.big-NOM } & \text { roaring-NOM } & \text { and bellowing-NOM entire-GEN } & \text { people-GEN } \\ \text { est cum fletu, } & \text { [ut forsitan porro ad } & \text { ciuitat-em } \\ \text { be.PRS.3SG with crying.ABL } & \text { that perhaps further to city-ACC } \\ \text { gemitu-s } & \text { popul-i } & \text { omni-s } & \text { audit-us } & \text { si-t]. } \\ \text { moaning-NOM people-GEN } & \text { entire-GEN heard-NOM.M.SG } & \text { be.PRS.SBJV-3SG }\end{array}$

'Such was the roaring and bellowing, moaning and crying of the entire people, that their outbursts were perhaps heard in the city.' (Itinerarium Egeriae 36.3)

In this example, the event described in the matrix clause (people moaning and crying) and the hearing event in the embedded clause (cf. auditus sit) are best understood as taking place (quasi-)simultaneously, as we are arguably dealing with a case of direct auditory perception. ${ }^{3}$ Therefore, the expression auditus sit in the embedded clause is in all likelihood a genuine present subjunctive. Elsewhere in Egeria's text, we find a very comparable passage describing essentially the same situation, but here the subjunctive in the embedded clause appears as the single synthetic verb audiantur (i.e. what one would get in Classical Latin), which unambiguously is a present subjunctive:

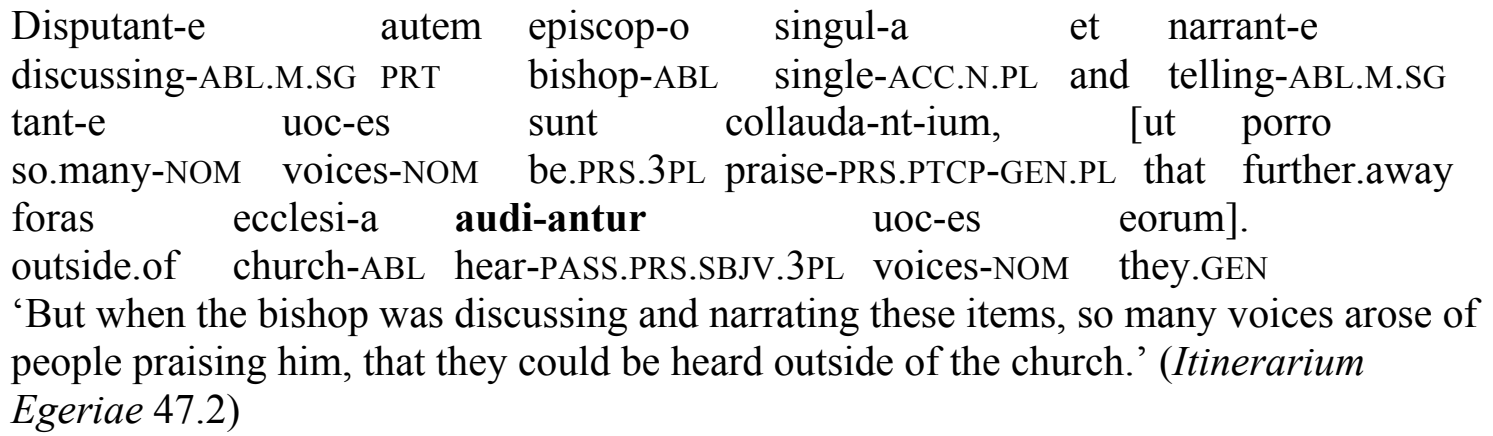

\footnotetext{
${ }^{3}$ In Classical Latin, the combination of a present subjunctive of $\mathrm{BE}$ with a past participle (which is formally identical to what we see in (5)) is also allowed in resultative $u t$-clauses, but there it qualifies as a perfect subjunctive and indicates anteriority with respect to the event in the matrix clause.
} 
In sum, as the interpretation of the example in (5) also doesn't favour an adjectival (stative or resultative) reading of the expression auditus sit, we can safely conclude that this is a genuine example of the new, 'Romance-type' passive.

\subsection{The standard account}

There is a broad consensus that the disappearance of the synthetic passive does not only happen later than the shift from $\mathrm{E}$ to $\mathrm{F}$ in the perfectum, but that there is also a causal relation between the earlier and the later development. More particularly, the standard assumption is that once the F-periphrases were well established, the entire voice paradigm was analogically levelled, yielding only periphrases of the 'no tense mismatch' type (on the role of analogy in this process, see among others Clackson and Horrocks (2007: 280) and de Melo (2012)). In what follows, I will assume that this is correct.

In addition however, most authors assume that the formal resemblance between the old E-periphrases (amatus est) and the new analytic present tense passives (sono amato) is no coincidence. The relation between the two patterns is typically explained in the following terms. First, it is pointed out that E-periphrases are often ambiguous between an adjectival reading (with a present tense copula and a predicative adjective) and a purely verbal one. The former qualify as present tenses, whereas the latter are perfects. Next, once F-periphrases had become the standard way to express passive perfects, the old E-periphrases only kept their non-past (adjectival) meaning. The development from an adjectival present tense passive towards a verbal present passive is then assumed to be a small step. A scenario along these lines is for instance outlined in Hewson (1997: 315): ${ }^{4}$

'The passive perfect laudātus est "he has been praised" is made up of the perfect participle (passive) and the present (Infectum) auxiliary of the verb esse "to be", so that in analytic terms the whole formation was the equivalent of "he is praised", where [...] we see the confusion between the perfect and the passive. [...] a perfect passive with a present auxiliary may be interpreted as an ordinary present passive.'

Under this at first glance simple and elegant scenario, one and the same structure (viz. the combination of a present tense BE-auxiliary and a past participle) changes meaning. As it stands, this account is not a priori implausible, although it would remain to be made precise

${ }^{4}$ This standard account assuming a direct connection between Latin perfects and the Romance present tenses comes in a number of versions, sometimes differing in the details. Compare the following quotes:

'The central immediate cause of the shift [...] was the need to communicate temporal information. Within the analytic tenses, ambiguities were already present in C[lassical] L[atin], e.g. the dual meaning of the p. ptc. + ESSE: amatus est 'he is loved, beloved' with the p. ptc. functioning as an adjective, and 'he has been loved', a perfect passive expression [...]. It was the ambiguity of tense within a single expression that motivated the change [...].' (Winters 1984: 450-1)

'In Italian, Latin amor is replaced by sono amato, from amatus sum, which has acquired present meaning.' (de Melo 2012: 84)

Other proponents of (variants of) this 'standard account' include Ernout and Thomas (1953': 228-9), Harris (1978: 188), Väänänen (1981³: 129-30), Ledgeway ([1997] 1999: 117) and Clackson and Horrocks (2007: 280). 
how exactly the meaning of an adjectival passive can be extended so as to express (present tense) verbal passives too. In the remainder of this paper, I will develop a slightly different proposal, which does not assume a direct connection between amatus sum and sono amato. Instead, the latter type will be argued to be an entirely new formation, whose origins can be traced back to Late Latin.

\section{Some overlooked evidence: word order}

One important aspect of the development of Latin BE-periphrases which until now has not received any attention in the literature is word order. In this section, I will present a series of new generalizations on this topic, which I will claim shed some interesting light on the developments just outlined.In order to document word order preferences in BE-periphrases in the history of Latin, I have analysed a corpus of Latin prose texts (starting with Cato, at about 160 BC) until Gregory of Tours (end of the $6^{\text {th }}$ century AD).$^{5}$

\subsection{A surprising discrepancy}

As is well known, Latin auxiliaries and their non-finite (infinitival or participial) complements can be linearized in either order (see among others Ledgeway (2012: 234-5) and Adams (2013: 821-38), and references cited there). Such is for instance the case in clauses with a modal auxiliary (like possum 'be able') and a dependent infinitive:

(7) ut omni-s contio audi-re pos-se-t vPAux so.that whole-NOM gathering.NOM hear-PRS.INF be.able-IPFV.SBJV-3SG 'so that the entire gathering may be able to hear' (Cicero, Pro Cluentio 134)

(8) ut nemo [...] uoc-em acerb-am atque inimic-am

AuxVP so.that nobody.NOM word-ACC bitter-ACC and hostile-ACC bon-is pos-se-t audi-re good-DAT.M.PL be.able-IPFV.SBJV-3SG hear-PRS.INF 'so that nobody could hear any bitter or hostile word uttered against the good citizens' (Cicero, Post reditum in senatu 26)

In contrast, the present day Romance languages are characterized by a strictly head-initial TP. Interestingly, corpus data show that the shift towards this new system was already going on in Latin. Clauses with the modal possum constitute a very clear case. As can be seen in Figure 1,

\footnotetext{
${ }^{5}$ The following works were taken up in the corpus (for each author all non-fragmentary prose texts were considered, unless mentioned otherwise): Cato (160 BC), Cicero (selection of prose works, $60 \mathrm{BC})$, Caesar (50 BC), Varro (45 BC), Sallust (40 BC), Hyginus ( astronomia, $20 \mathrm{BC}$ ), Vitruvius (0 AD), Livy (5 AD), Celsus (30 AD), Seneca (selection of prose works, $50 \mathrm{AD}$ ), Columella (55 AD), Petronius (60 AD), Frontinus (90 AD), Quintilian (95 AD), Pliny the Younger (100 AD), Tacitus (110 AD), Suetonius (120 AD), Gaius (170 AD), Tertullian (Aduersus Marcionem 1-5, 210 AD), Cyprian (Epistulae 1-76, except 4, 57, 61, 64, 67, 70 and 72, 255 AD), Palladius (350 AD), Itinerarium Egeriae (385 AD), Jerome (Epistulae 1-30 (except 19), 60-80, 390 AD), Augustine (Sermones 1-10, 101-113A, 201223E, 301-313A, 400 AD), Gesta Conlationis Carthaginiensis (411 AD), Vegetius (420 AD), Cassius Felix (447 AD), Victor of Vita (490 AD), Pompeius Maurus (500 AD), Caesarius of Arles (Sermones 1-80, 520 AD), Anthimus (535 AD), Iordanes (550 AD), Itinerarium Antonini Placentini, 570 AD), Gregory of Tours (Historiae, 590 AD).
} 
despite there being a fair amount of synchronic variation throughout the entire period, a steady rise of the head-initial order can be observed, as witnessed by the trajectory of both the straight and the smoothed regression line: ${ }^{6}$

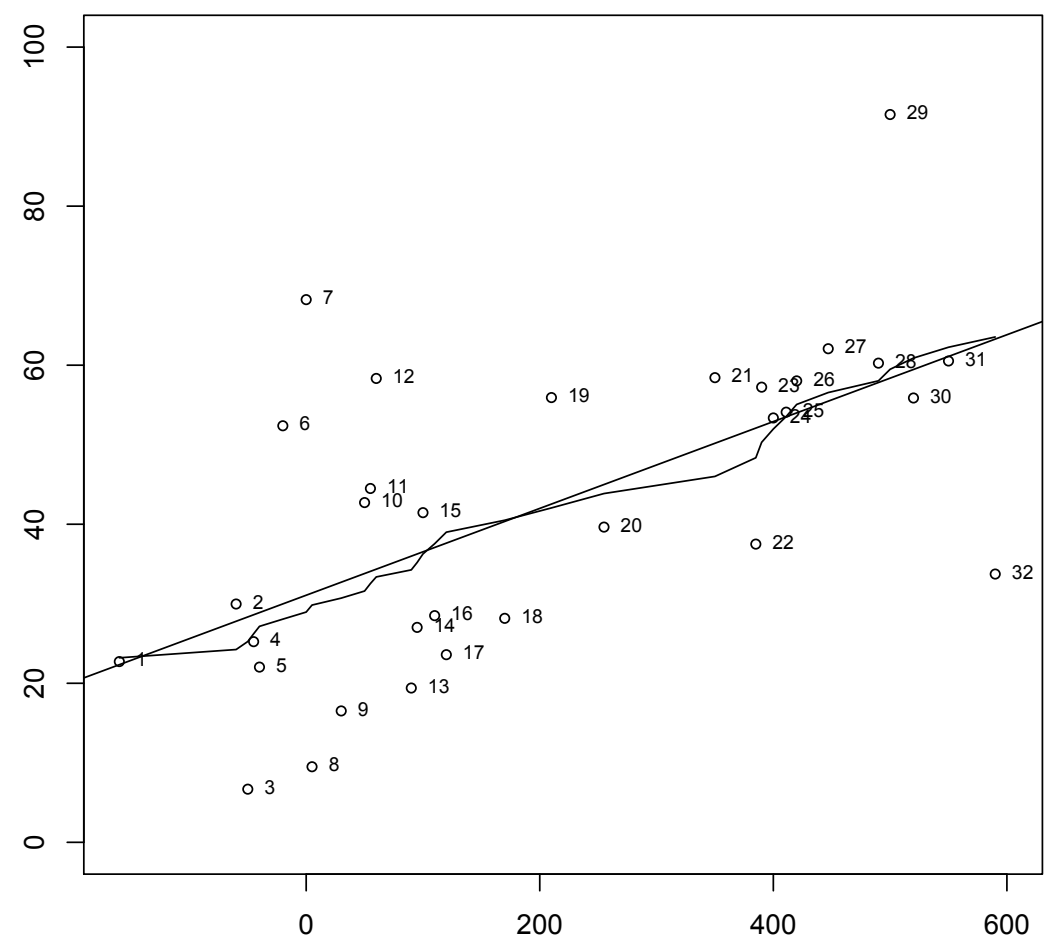

Figure 1: Relative frequency (in percentages) of the order 'possum - infinitive' over time. Case labels: $1=$ Cato, $2=$ Cicero, $3=$ Caesar, $4=$ Varro, $5=$ Sallust, $6=$ Hyginus, $7=$ Vitruvius,

$8=$ Livy, $9=$ Celsus, $10=$ Seneca, $11=$ Columella, $12=$ Petronius, $13=$ Frontinus, $14=$ Quintilian, $15=$ Pliny, $16=$ Tacitus, $17=$ Suetonius, $18=$ Gaius, $19=$ Tertullian, $20=$ Cyprian, 21= Palladius, 22= Itinerarium Egeriae, 23= Jerome, 24= Augustine, 25= Gesta Conlationis

Carthaginiensis, 26= Vegetius, 27 $=$ Cassius Felix, 28= Victor of Vita, 29= Pompeius Maurus, $30=$ Caesarius of Arles, $31=$ Iordanes, $32=$ Gregory of Tours.

A similar (albeit milder) development can be observed in clauses with the modal auxiliary debeo 'have to' (cf. Figure 2), suggesting that the tendency observed in Figure 1 is not accidental.

\footnotetext{
${ }^{6}$ For the sake of simplicity, in this and the following graphs I am lumping together cases where the auxiliary and the non-finite verb are string adjacent with cases where they are not. Nothing crucially hinges on this (see also note 6). In addition, each time I only report on data from the authors/texts listed in footnote 4 which contain at least 20 tokens of a given auxiliary complemented by a non-finite verb.
} 


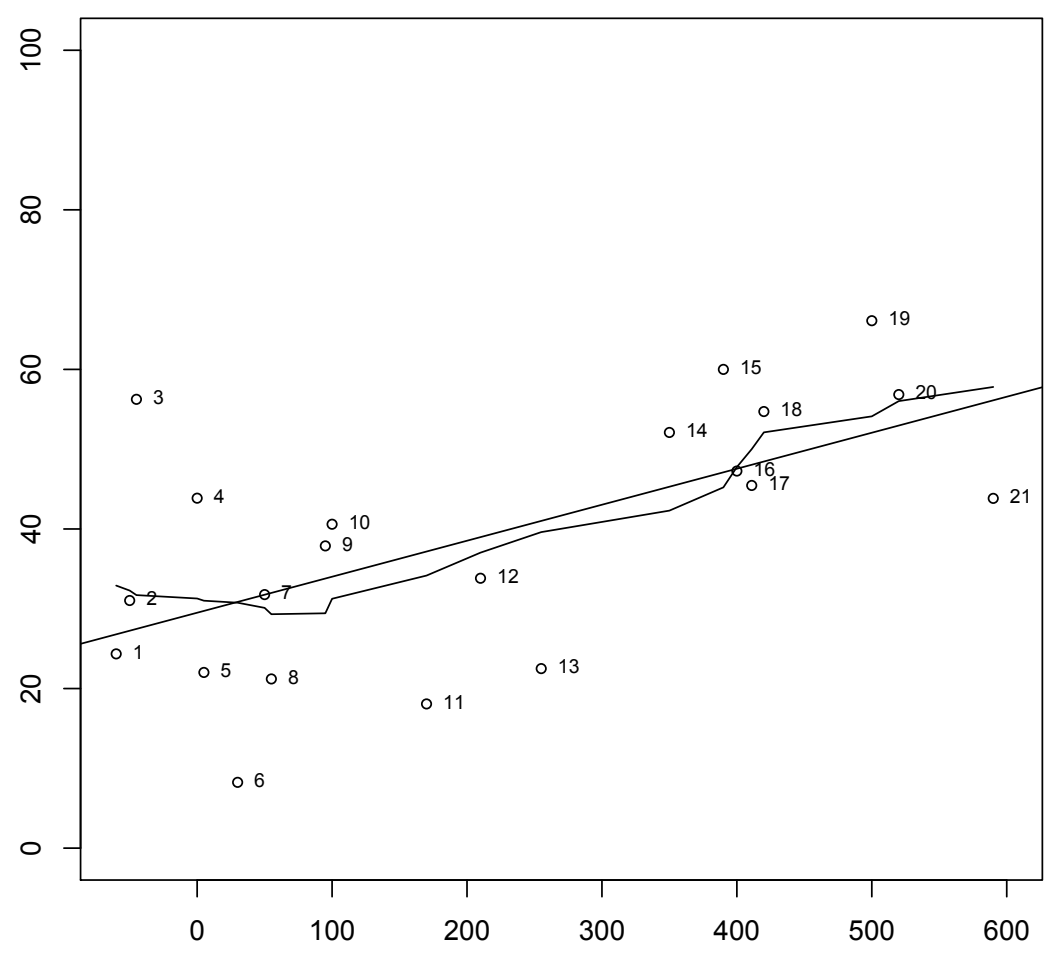

Figure 2: Relative frequency (in percentages) of the order 'debeo - infinitive' over time. Case labels: $1=$ Cicero, $2=$ Caesar, $3=$ Varro, $4=$ Vitruvius, $5=$ Livy, $6=$ Celsus , $7=$ Seneca, $8=$

Columella, 9= Quintilian , 10= Pliny, 11= Gaius, 12= Tertullian , 13= Cyprian, 14=

Palladius, 15= Jerome, 16= Augustine, 17= Gesta Conlationis Carthaginiensis, 18=

Vegetius, 19= Pompeius Maurus, 20= Caesarius of Arles, 21= Gregory of Tours.

The crucial observation is that the alternation between the orders amatus est and est amatus shows a very different picture. As shown in Figure 3 (which only contains data on Eperiphrases), no rise of the head-initial order can be observed. Instead, without a single exception all Late Latin authors heavily favour the head-final order amatus est: ${ }^{7}$

\footnotetext{
${ }^{7}$ Note that the observed effect is not to be ascribed to increasing frequencies of leftward movement of the past participle (yielding a structure in which the non-finite verb and the auxiliary are not (structurally) adjacent), as a reviewer suggests. Such an operation does indeed exist, but it clearly is a minority pattern: in only 1004 out of a total of 19157 head-final E-periphrases, the past participle and the auxiliary are not linearly adjacent (cases where $\mathrm{PaPa}$ and Aux are only separated by negation not taken into account, for reasons discussed in Danckaert (2017: ch. 5, to appear)). In addition, the frequency of leftward participle movement - if the non-contiguous patterns are indeed to be analysed in these terms - declines over time: out of 8909 head-final E-periphrases dating from before $150 \mathrm{AD}, 830(9.32 \%)$ tokens are discontinuous. For the period after $150 \mathrm{AD}$, the corresponding figures are 174 instances $(1.70 \%)$ out of a total of 10248 .
} 


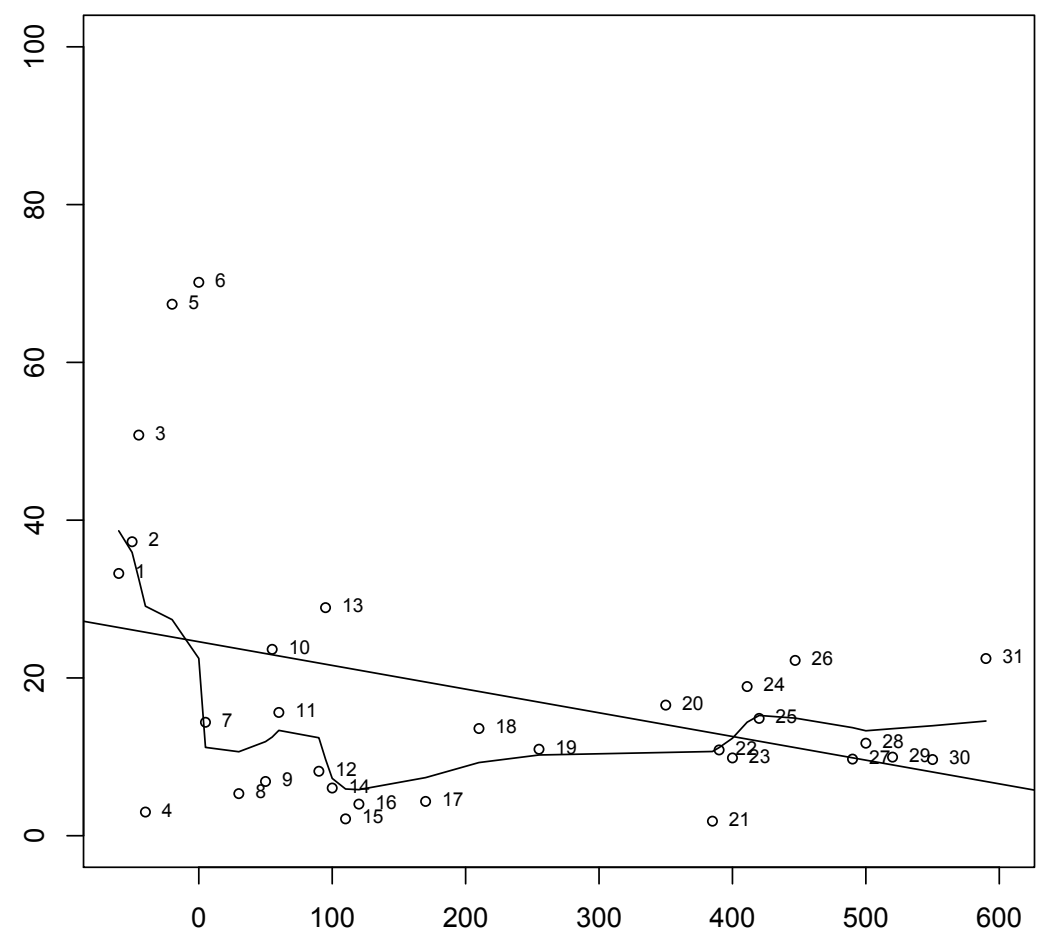

Figure 3: Relative frequency (in percentages) of the order ' $\mathrm{BE}$ - past participle' in passive and deponent E-periphrases over time. Case labels: 1= Cicero, 2= Caesar, 3= Varro, 4= Sallust, 5= Hyginus, $6=$ Vitruvius, $7=$ Livy, $8=$ Celsus, $9=$ Seneca, $10=$ Columella, $11=$ Petronius,

$12=$ Frontinus, $13=$ Quintilian, $14=$ Pliny, $15=$ Tacitus, 16= Suetonius, $17=$ Gaius, $18=$

Tertullian, 19= Cyprian, 20= Palladius, 21=Itinerarium Egeriae, 22= Jerome, 23= Augustine, 24= Gesta Conlationis Carthaginiensis, 25= Vegetius, 26= Cassius Felix, 27= Victor of Vita, 28= Pompeius Maurus, 29= Caesarius of Arles, 30= Iordanes, 31= Gregory of Tours.

As can be deduced from the irregular trajectory of the smoothed regression line, it is probably not warranted to say that there is a real decline of the head-initial order. Rather, what we seem to witness is a loss of word order flexibility, resulting in a 'fossilization' of the head-final pattern. In any event, the E-periphrases clearly do not behave like the modals, and they certainly do not display the type of behaviour one expects from a structure that evolves towards the Romance languages. Crucially, these unexpected word order preferences are not a general property of BE-auxiliaries. As is shown in the final graph of this section, F-periphrases follow a diachronic path which is very different from that of their E-type counterparts: 


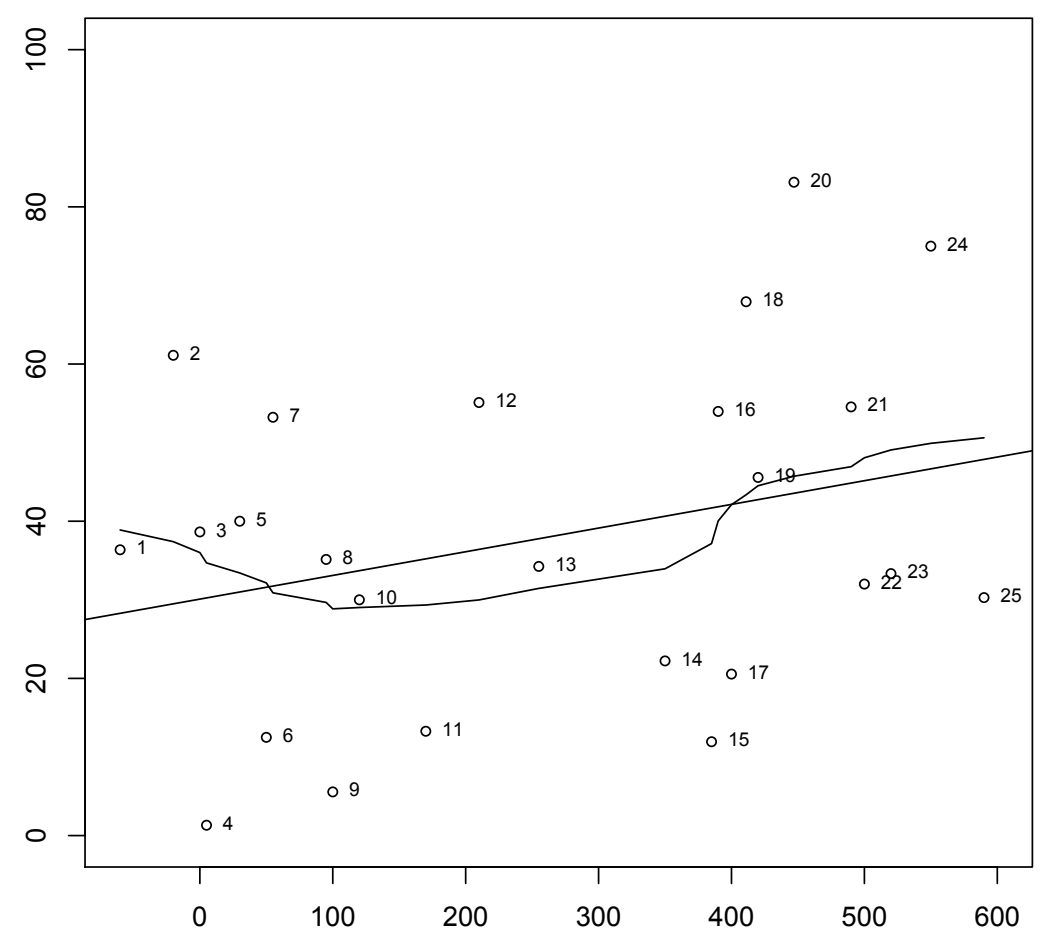

Figure 4: Relative frequency (in percentages) of the order 'BE - past participle' in passive and deponent F-periphrases over time. Case labels: $1=$ Cicero, $2=$ Hyginus, $3=$ Vitruvius, $4=$ Livy, $5=$ Celsus, $6=$ Seneca, $7=$ Columella, $8=$ Quintilian, $9=$ Pliny, $10=$ Suetonius, $11=$ Gaius, 12= Tertullian, 13= Cyprian, 14= Palladius, 15=Itinerarium Egeriae, 16= Jerome, 17= Augustine, 18= Gesta Conlationis Carthaginiensis, 19=Vegetius, $20=$ Cassius Felix, 21 $=$ Victor of Vita, 22= Pompeius Maurus, 23= Caesarius of Arles, 24= Iordanes, 25= Gregory of Tours.

Although the F-periphrases do not seem to behave exactly like the modals (there appears to be a rise of the head-initial order, but variation is considerable, and the upward trend is rather mild), there is a clear contrast with the E-periphrases. Crucially, here we do not observe any Late Latin preference for the order 'past participle - BE'.

\subsection{The origins of the 'no tense mismatch' passive: a simpler alternative}

Recall that the standard account on the origins of the Romance voice paradigm posits that Latin amatus est perfects live on in the Romance languages as present tense passives. Under this scenario, one would expect the relevant structure to take part in a change that otherwise affects the entire language system, namely the shifts towards a head-initial TP. Given that this is clearly not the case, the facts reviewed in the previous section constitute a major problem for the standard account, as the observed word order tendencies in E-periphrases remain entirely unexplained.

As an alternative, I would like to suggest a very simple solution which is only slightly different from what is standardly assumed, but which avoids the problem just sketched. Recall that previous studies strongly emphasized the role of analogical levelling in bringing about a passive paradigm which is entirely of the F-type ('no tense mismatch', see Clackson and Horrocks 2007; de Melo 2012). Assuming this to be correct, I propose that when they are being replaced by F-periphrases, Late Latin perfective E-periphrases do not change meaning but slowly disappear from the language. The innovative, 'no tense mismatch' Romance passives are then a new formation, created by analogy with the perfective F-periphrases, 
which as we have seen exhibit 'normal' Late Latin word order behaviour. This solution has at least two advantages over the standard account. First, it avoids the word order problem: the newly created present tense passives can be expected to be equally likely to be head-initial as their perfective counterparts (i.e. the older F-periphrases). Second, there is no need to explain the shift (extension) from an adjectival present tense passive (like amatus sum 'I am popular') towards a verbal present tense passive of the type sono amato 'I am (being) loved'. In all accounts known to me, the change from 'past-verbal/present-adjectival' to 'presentverbal/present-adjectival' is simply asserted to have taken place, but no details of the putative transition are ever made explicit, let alone formalized. Under the present approach, no such explanation is required, as there is no semantic change to begin with.

\subsection{A note on deponents and Romance unaccusatives}

Before moving on, I will first say a couple of words about present day Romance expressions like Italian sono venuto 'I have come'. Such (perfective) past tenses of unaccusatives feature a BE-auxiliary which in isolation would be a present tense, and thus clearly display the tense mismatch discussed above. It has been proposed that these structures are derived from Latin deponent E-periphrases (see for instance Ledgeway ([1997] 1999: 115-6)). Given the obvious formal similarities between expressions like Latin natus sum 'I was born' and mortuus sum 'I died (I am dead)' on the one hand, and Italian sono nato and sono morto on the other, this hypothesis certainly has some intuitive appeal.

However, there are also a number of problems with this idea. First of all, an obvious difference between Latin deponents and Romance unaccusatives is that unlike the latter, Latin deponents constitute a semantically very heterogeneous class of verbs, consisting of unaccusatives like morior 'die' and proficiscor 'depart, leave', unergatives like iocor 'jest, joke' and epulor 'dine, feast' and clear-cut transitives like adipiscor 'obtain' and consequor 'follow, pursue'. In other words, a direct transfer from Latin deponent unaccusatives (like natus sum) to Romance unaccusatives (sono nato) is of course straightforward enough, but both (i) the extension of the BE-perfect to other unaccusatives (like sono venuto, for which there is no Latin deponent counterpart) and (ii) the exclusion of all other predicate types (i.e. all Latin unergative and transitive deponents) would still have to be accounted for. Second, a line of reasoning very similar to the one developed above concerning the diachrony of Latin passives can be applied to deponents, as in the period under investigation (ca. $100 \mathrm{BC}-600$ $\mathrm{AD}$ ), the diachronic trajectory of these two types of BE-periphrases is virtually identical. For instance, when we look at the proportion of F-periphrases in passives and deponents (as shown in Figure 5), we see that the change from $\mathrm{E}$ to $\mathrm{F}$ affects passives and deponents in equal measure: ${ }^{9}$

\footnotetext{
${ }^{8}$ This is of course not to say that no generalizations can be made about the historical roots of many deponents, which often derive from medio-passives (Flobert 1975; Gianollo 2010). However, this clearly doesn't offer a satisfactory synchronic description of the relevant facts: whether or not a given verb is deponent (at a particular stage of the language) is a purely lexical idiosyncracy.

${ }^{9}$ Note that the fact that the frequency of F-periphrases increases over time does not obviously appear in Figure 5. As detailed in Danckaert (2016), the rise of the F-pattern is strongest in future perfects and (to a lesser extent) pluperfects, but these two categories are largely outnumbered by plain perfects, where the relevant change is much slower. Also, note that the apparently anomalously high frequency of F-periphrases in one data point in Late Latin (viz. Cassius Felix at $447 \mathrm{AD}$ ) is related to the fact that most BE-periphrases in this text happen to be future perfects.
} 


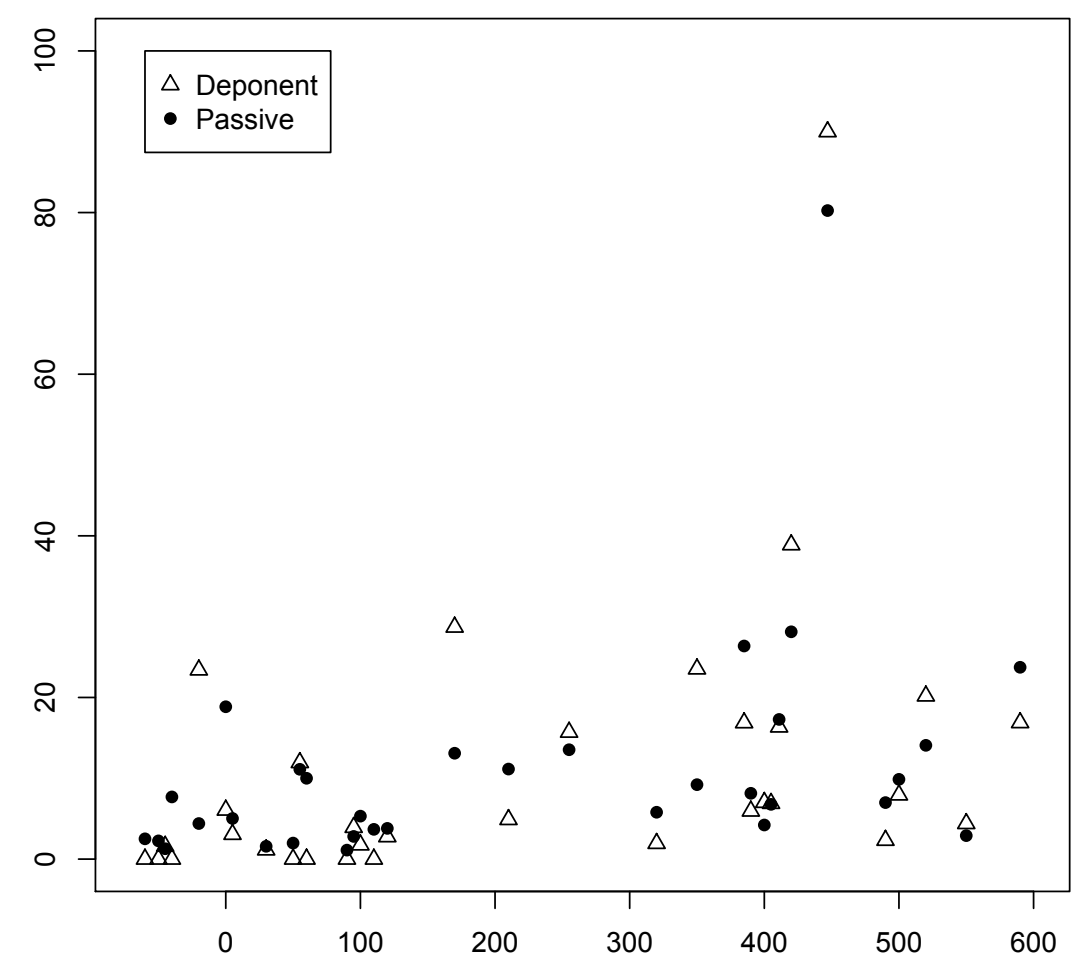

Figure 5: Relative frequency (in percentages) of deponent and passive F-periphrases (as compared to E-periphrases) over time.

From this data set we can conclude that Late Latin analytic deponents take part in the same shift from E to F, in more or less exactly the same way as their passive counterparts (see once again Danckaert (2016) for more detailed discussion of exactly this point). This can be considered evidence against an account that assumes direct continuity from (certain) Latin unaccusative deponents to Romance unaccusative BE-perfects. More specifically, what the (Late) Latin data suggest is that analytic deponents like natus sum do not remain stable over time, but rather (slowly) change to the type natus fui (fui natus).

In addition, if it is correct to think that the change from $\mathrm{E}$ to $\mathrm{F}$ in the perfectum on the one hand, and the change from synthetic to analytic in the infectum on the other are part of one larger integrated development (viz. the reorganization of the entire Latin passive voice paradigm, cf. section 2), we predict that if the diachronic trajectory of passives and deponent analytic verb forms is indeed not differentiated, Late Latin deponent E-periphrases should also display a preference for the order ' $\mathrm{PaPa}$-Aux'. As shown in Figure 6, this is indeed the case: ${ }^{10}$

${ }^{10}$ Only E-periphrases were included in this data set, and only data from authors/texts with at least 10 deponent tokens. 


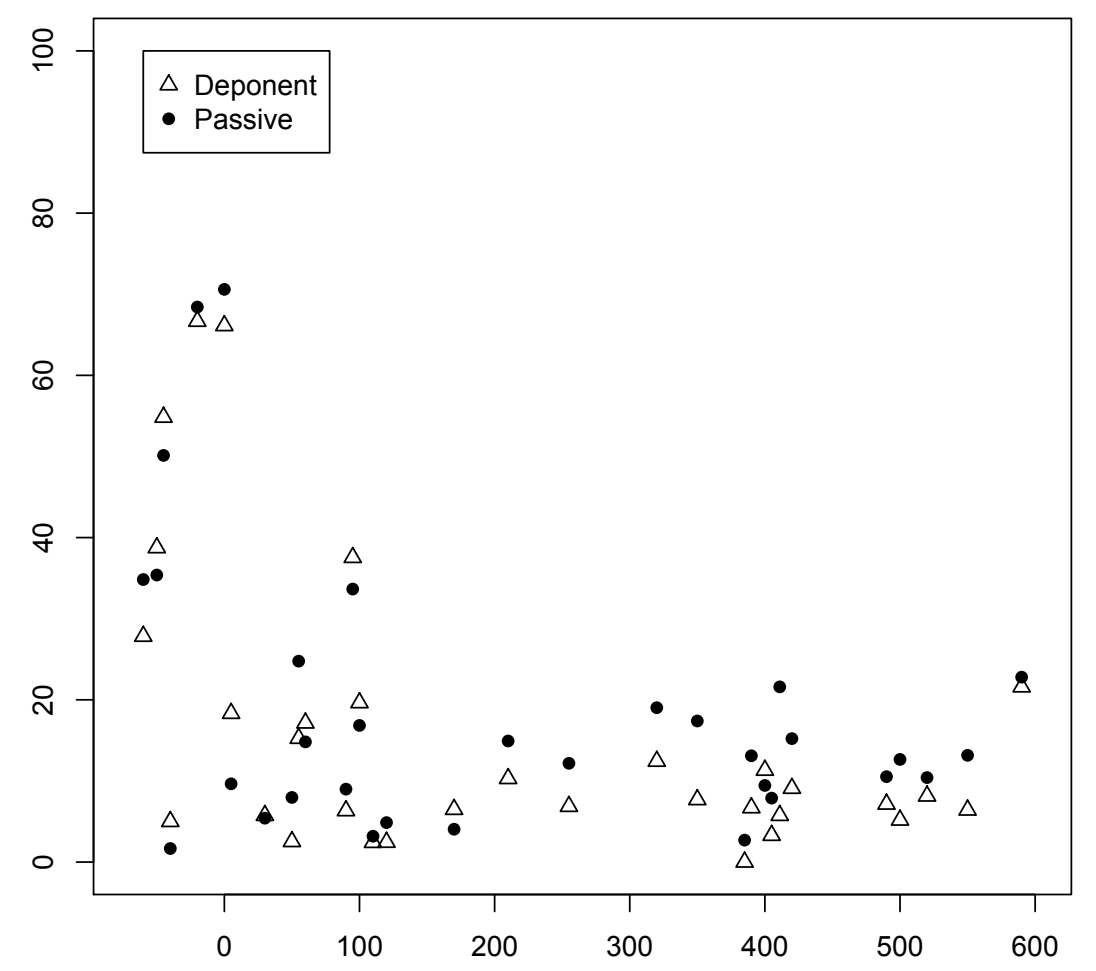

Figure 6: Relative frequency (in percentages) of the order ' $\mathrm{Aux}-\mathrm{PaPa}$ ' in E-periphrases over time, passives and deponents compared.

Assuming that the Late Latin preference for the ' $\mathrm{PaPa}$ - Aux' order is correlated with the fact E-periphrases were dying out (and thus did not take part in an otherwise general change towards a head-initial T-node), these facts too suggest that Latin natus sum might actually not be that closely related to Italian sono nato, despite formal similarities.

To conclude, given the above considerations, and extending the logic developed in section 3.2, one can reasonably hypothesize that Romance periphrases of the sono nato/sono venuto type are also new formations (whose origins are arguably related to the rise of analytic HAVE-perfects, cf. Ledgeway ([1997] 1999)). One only needs to add the proviso that the proposed new perfects probably came into being (much) later than the new present tense passives (which are attested as early as the $4^{\text {th }}$ century AD, cf. section 2.1 .2 above).

\section{Towards an analysis of the word order facts}

In the remainder of this paper I will offer some additional discussion of the unexpected (and hitherto unnoticed) Late Latin preference for head-final E-periphrases. For reasons of space, here I will only provide a summary of the account. A detailed analysis can be found in Danckaert (2015).

In a nutshell, I take it that the word order facts shown in Figure 3 are to be understood in terms of a PF-constraint on the placement of the auxiliary, which I take to have acquired clitic-like properties. More specifically, I assume a lexical split between a strong (phonological independent) and a weak variant of BE. ${ }^{11}$ The strong variant, which is the same

\footnotetext{
${ }^{11}$ Note that the phonological weakening of BE which I am about to analyse is different from (i) BE-contraction of the type described in Pezzini (2011), which only affects forms of esse with a vocalic onset and which is restricted to Archaic and early Classical Latin, as well as from (ii) certain (putative) 'second position' phenomena which have been analysed in terms of BE-cliticization (Adams 1994).
} 
as in earlier stages of the language, appears in contexts which are preserved in Romance, viz. copular clauses (including adjectival passives of various kinds) and verbal F-periphrases. ${ }^{12}$ In contrast, in E-periphrases we get the weak version, which displays the unexpected word order behaviour described in section $3 .^{13}$

\subsection{Weak BE, and prosodic restrictions on word order}

The key ingredient of the proposal is that weak BE is not a genuine clitic (which BE can be in English and in many Slavic languages), but rather a category which is somewhere in between a full lexical item and a true clitic. This proposal is clearly reminiscent of accounts where structurally deficient variants of full lexical items are said to come in (at least) two versions, called $X^{\max }$ and $X^{\circ}$ clitics in Halpern and Fontana (1994), and weak and clitic items in Cardinaletti and Starke (1999). In both of these analyses however, the difference between weak elements and true clitics is argued to involve a difference in phrase structure: the former are taken to be (reduced) phrases, whereas the latter are considered syntactic heads. In the present context, I will assume that both manifestations of Latin BE are heads (as they are obviously 'verbal'), but that the lexical entry corresponding to them is slightly different. ${ }^{14}$ Concretely, I take it that whereas both are identical in terms of semantic feature composition, they differ as to their phonological realization.

Assuming a standard version of the prosodic hierarchy (see Selkirk (1980, 1984), Nespor and Vogel ([1986] 2007²), and much related literature) I will take it that prosodic words - which are themselves composed of one or more feet $(\mathrm{F})$ - are grouped together to form phonological phrases $(\varphi)$ (I am abstracting away from clitic groups). Next, I will assume that strong BE always constitutes an independent prosodic word $(\omega)$ of its own, but that weak BE can never project a prosodic word of its own. Instead, I propose that the latter is a 'stray' metrical foot which can only survive if it occurs in an extrametrical position at the right edge of a phonological phrase.

Consider the three structures in (9), where ' $F$ ' represents weak BE:

(9)

a. *

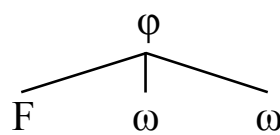

b. *

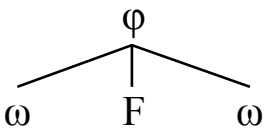

c.

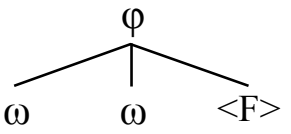

\footnotetext{
${ }^{12}$ I remain agnostic as to whether copular and auxiliary BE are themselves separate lexical entries.

${ }^{13}$ It is possible that weak BE also occurs in other environments which do not survive in Romance, like deontic constructions involving BE and a gerundive, as in (i):
}
(i) prius
instrument-a
praepara-nd-a
sunt
before.COMP.ADV tools-NOM
prepare-GDV-NOM.N.PL be.PRS.3PL
'first the tools have to be prepared.' (Columella, De agricultura 2.18.3)

I leave it to future research to verify whether this structure also favours the head-final order, which would be compatible with the idea that it involves weak BE.

${ }^{14}$ Alternatively, one could assume that all lexical items are actually phrasal, and that there is actually a difference between two or more types of Latin BE which corresponds to a difference in size (shape). An account along these lines could be worked out in the framework of nanosyntax (Starke 2014). 
Assuming that extrametrical material can only occur at the right edge of phonological domains (Hyde 2011: 1045-7), it follows that the only context in which weak BE can be incorporated in a well-formed phonological phrase is $(9 \mathrm{c})$, where the extrametrical status of the final foot is indicated by means of angle brackets. This phonological 'escape hatch' for weak BE is not available in the other two structures diagrammed in (9), where the weak element occurs at the beginning (9a) or in the middle (9b) of a phonological phrase.

As elaborated on in Danckaert (2015), this analysis effectively derives the abundance of Late Latin 'past participle - BE' patterns, as only auxiliaries in head-final T-projections have a chance of ending up at the end of a phonological phrase.

\subsection{No $\mathrm{X}^{\circ}$-incorporation ('true cliticization'): placement of negation in VPAux-clauses}

An obvious alternative to the account just sketched is to say that the Late Latin preference for head-final BE-periphrases involves (en)cliticization through syntactic head movement. Under this approach, the auxiliary would be an affix in $\mathrm{T}$, and the lexical verb would incorporate to it. The relevant structure would look as in (10), which does indeed feature the desired linear order ' $\mathrm{PaPa}$ - Aux' (assuming the incorporating head to left-adjoin to its host):

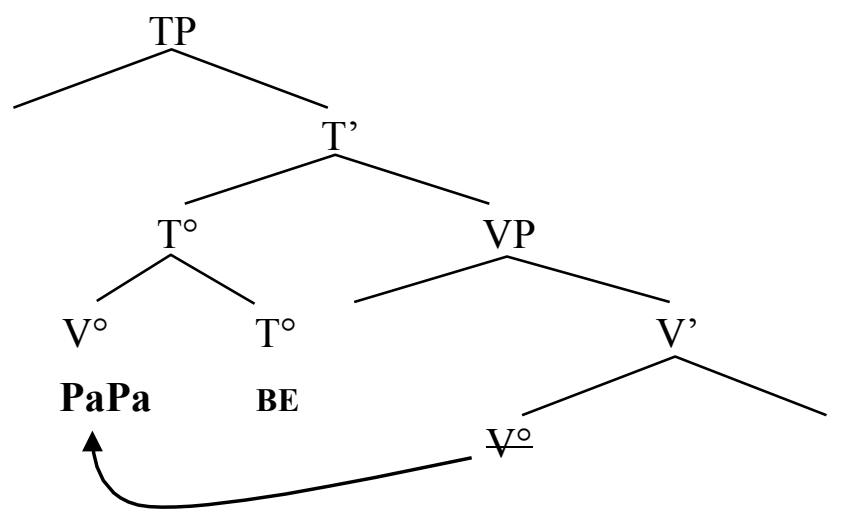

Assuming head movement to take place in a strictly local fashion, this account predicts the lexical verb and the auxiliary to show 'clustering' effects, in the sense that they would either be strictly adjacent, or separated from one another only by heads which are base generated below $\mathrm{T}$, and which incorporate into $\mathrm{V}$ before the latter head moves to $\mathrm{T}$. However, there are good reasons to assume that Late Latin participles and BE-auxiliaries are not actually structurally contiguous, as a head movement account would predict. Evidence for this comes from placement of negation in clauses with a head-final BE-periphrasis.

The basic facts concerning placement of negation in Latin are as follows. First of all, there is an exceptionless generalization to the effect that the canonical marker of sentential negation non 'not' always precedes the hierarchically highest verb in the clause. This generalization can be considered to follow from (i) the fact that non is first merged higher than $\mathrm{T}$ and from (ii) independent locality principles which make sure that the verb in $\mathrm{T}^{\circ}$ cannot move across negation (say the Head Movement Constraint, assuming non to be a head). Second, although there is a clear tendency for non and the highest verb to be linearly adjacent (as they are in (11)), at all stages of the language non can also appear in more leftward positions (see Kühner and Stegmann (1966': vol. 2.1, 818-9) for additional discussion). For instance, in (12) we find the string 'Neg - PaPa - Aux':

$\begin{array}{lllll}\text { (11) pro qu-o } & \text { frument-o } & \text { pecuni-a } & \text { omni-s } \\ \text { for which-ABL } & \text { corn-ABL } & \text { money-NOM } & \text { all-NOM } \\ \text { solut-a } & \text { non } & \text { est } & & \end{array}$


paid-NOM not be.PRS.3SG

'In exchange for this corn not the entire sum of money was paid.'

(Cicero, Diuinatio in Q. Caecilium 32)

(12)
illud
si incid-it,
hoc
non sequut-um
est
this.NOM.N.SG if befall-PRS.3SG that.NOM.N.SG not followed-NOM.N.SG be.PRS.3SG
'if the former happens without the latter following' (Celsus, De medicina 2.17.6)

Here I will not be concerned with the proper analysis of the syntax of sentential negation in Latin, which is dealt with in Danckaert (2017, to appear): I will simply assume that the data in (11) and (12) reflect the availability of multiple NegPs in the higher functional field (Zanuttini 1997; Cinque 1999: 120-6). Instead, I will focus on one particular prediction one makes when assuming a structure like (10) for Late Latin BE-periphrases: if the latter are indeed derived by means of V-to-T movement, we expect that in VPAux-clauses, the order 'Neg - PaPa - Aux' should become more frequent over time, at the expense of the alternative order ' $\mathrm{PaPa}-\mathrm{Neg}$ Aux', which arguably does not involve head movement of V across Neg (which would violate the Head Movement Constraint), but rather (remnant) VP movement past negation (of the type discussed in Danckaert 2012, 2014, 2017).

Corpus data suggest that this prediction is not borne out. As shown in Table 4, negated BE-periphrases of the type amatus non est remain productive until well after ca. 150 AD (cf. the shaded cells), which is when the order ' $\mathrm{PaPa}$ - Aux' seems to have fossilized:

Table 4: Frequency of the orders 'PaPa - Neg - Aux' and 'Neg - PaPa -Aux' in BE-periphrases of the E-type (only authors/texts with at least 4 negated E-periphrases included).

\begin{tabular}{|l|l|c|c|}
\hline Author & Date & $\begin{array}{c}\text { PaPa - Neg - Aux } \\
\text { (amatus non est) }\end{array}$ & $\begin{array}{c}\text { Neg - PaPa -Aux } \\
\text { (non amatus est) }\end{array}$ \\
\hline Cicero & $60 \mathrm{BC}$ & $62(79.49 \%)$ & $16(20.51 \%)$ \\
\hline Varro & $45 \mathrm{BC}$ & $4(66.67 \%)$ & $2(33.33 \%)$ \\
\hline Livy & $5 \mathrm{AD}$ & $5(27.78 \%)$ & $13(72.22 \%)$ \\
\hline Celsus & $30 \mathrm{AD}$ & $18(85.71 \%)$ & $3(14.29 \%)$ \\
\hline Seneca & $50 \mathrm{AD}$ & $6(50 \%)$ & $6(50 \%)$ \\
\hline Columella & $55 \mathrm{AD}$ & $7(77.78 \%)$ & $2(22.22 \%)$ \\
\hline Quintilian & $95 \mathrm{AD}$ & $16(84.21 \%)$ & $3(15.79 \%)$ \\
\hline Suetonius & $120 \mathrm{AD}$ & $3(60 \%)$ & $2(40 \%)$ \\
\hline Gaius & $170 \mathrm{AD}$ & $30(100 \%)$ & $0(0 \%)$ \\
\hline Tertullian & $210 \mathrm{AD}$ & $8(88.89 \%)$ & $1(11.11 \%)$ \\
\hline Cyprian & $255 \mathrm{AD}$ & $6(66.67 \%)$ & $3(33.33 \%)$ \\
\hline Augustine & $400 \mathrm{AD}$ & $11(50 \%)$ & $11(50 \%)$ \\
\hline Pompeius Maurus & $500 \mathrm{AD}$ & $1(25 \%)$ & $2(75 \%)$ \\
\hline Gregory of Tours & $590 \mathrm{AD}$ & $2(50 \%)$ & $2(50 \%)$ \\
\hline
\end{tabular}

Despite the small number of tokens in some of the later authors ${ }^{15}$, it seems safe to conclude that the fixation of the order ' $\mathrm{PaPa}$ - Aux' in Late Latin E-periphrases does not go hand in

\footnotetext{
${ }^{15}$ As it happens, word order in Late Latin negated clauses with a BE-periphrases is much more complicated and can not be done justice to here: see Danckaert $(2015,2017$ : 283-4) for full discussion.
} 
hand with a requirement for the participle and the auxiliary to be strictly linearly adjacent, witness the continuing availability of the order ' $\mathrm{PaPa}$ - Neg - Aux'.

\section{An interesting parallel: the genesis of the Romance synthetic future}

I will conclude this paper by discussing an interesting parallel with the development of BEperiphrases in the history of Latin, namely the oft-discussed rise of the Romance future and conditional. As is well known, these structures are the result of a grammaticalization process whose input is a (Late) Latin periphrastic structure involving an infinitive and the verb habeo 'have' (see among others Thielmann 1885; Rohlfs 1922; Valesio 1968, 1970; Coleman 1971, 1976; Clancy 1975; Pinkster 1985; Adams 1991, 2013: 625-73; Roberts 1992; Bourova 2005, 2007). The first known attestation of the Romance synthetic future is given in (13), which according to Stimm (1977) can be dated at ca. 550-600 AD (see also Ledgeway 2012: 136-7):

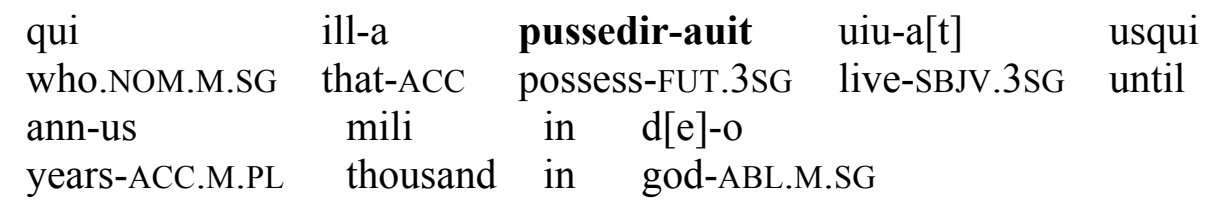

'May he who shall possess this live for a thousand years in God.' (inscription on a

Merovingian buckle found in Ladoix-Serrigny (France, Côte-d'Or), cf. Stimm 1977)

In this example, the future tense marker -auit is still bisyllabic, and thus quite transparently related to Latin habet. In (14) on the other hand, from around 650, the old synthetic future dabo 'you will give' appears alongside its synonymous successor daras, in which the future tense marker is now monosyllabic (cf. -as, cf. Latin habes):
(14) et ill-e
responde-ba-t:
'non da-b-o'.
and he-NOM
answer-IPFV-3SG
not
give-FUT-1SG
Iustinian-us
dic-eba-t:
'dar-as'.
Iustinianus-NOM
say-IPFV-3SG
give-FUT.2SG
'And he answered: 'I will not give'. // Iustinianus said: 'you will give'.'
(Fredegarius scholasticus, Scripta Rerum Merovingorum 2.2.62 (p.85 1.32))

The form daras corresponds to Latin dare habes (lit. 'give you.have'), but the HAVE-verb clearly has changed both meaning and syntactic/phonological shape. Interestingly, there is good evidence to assume that early on, the future marker was not yet a clear-cut verbal affi Thus Roberts (1992: 230):

It is well-known that Old Spanish (OSp) and conservative European Portuguese (EP) have future and conditional markers which are more clitic-like than affix-like. [...] $[\mathrm{T}]$ hey are halfway between being auxiliaries and being affixes.

Evidence for non-affixal status of the grammaticalized future marker comes from the availability of mesoclisis, a phenomenon whereby a pronominal clitic intervenes between the lexical verb and the future marker. This pattern was available in many Old Romance varieties (see for instance Old Spanish (15)), and survives until today in varieties of European Portuguese (16).

(15) Senora, - dixo el - dezir=lo hedes a-l rey?
lady said he tell=it you.will to-the king 
'Lady, he said, will you tell it to the king?' (Libro del caballero Zifar 124, cf. Lema and Rivero 1989: 250, their (21a))

(16) Ele $\mathbf{v e}=\mathbf{l a}=\mathbf{a}$.

he $\quad$ see.INF $=$ CL.ACC.F.3SG $=$ FUT.3SG

European Portuguese

'He will see her.' (cf. Duarte and Matos 2000: 117, their (5))

In whatever way they are to be analysed, these interpolation phenomena are of course reminiscent of the (Late Latin) 'PaPa - Neg - Aux' pattern: in both cases, the 'light' auxiliary follows its lexical complement, without there being any strong adjacency requirement. It is therefore tempting to conjecture that the grammaticalization process that gave rise to the synthetic future went through a 'weak HABEO' stage, in which the future marker was subject to the same constraint as the one governing placement of weak BE, as proposed in the previous section.

However, the parallel between the passive/deponent ' $\mathrm{PaPa}-\mathrm{BE}$ ' sequences and the new synthetic future is clearly only partial. First of all, only in the case of phonological weakening of HAVE is there any process of grammaticalization (meaning change) involved. Second, if the analysis proposed in section 3 is on the right track, E-periphrases died out, whereas the HAVE-futures are until today very much alive in many Romance varieties. Related to this, the comparison between the two developments also suggests that there is no principled (causal) relation between phonological weakening of Late Latin $\mathrm{BE}$ and the ultimate disappearance of E-periphrases. Rather, the latter development is in all likelihood first and foremost a matter of competition with (perfective) F-periphrases (whose origins remain to be better understood).

\section{Conclusion}

The goal of this paper was to reconsider the development of Romance present tense passives of the type sono amato 'I am loved'. I have argued that these are not derived from Classical Latin analytic perfects, contrary to what is standardly assumed. Instead, I have proposed that the Romance pattern is a new formation, which goes back to at least the $4^{\text {th }}$ century AD. The main advantage of this new approach is that it is compatible with the observation that Late Latin amatus est perfects show a very strong preference for the otherwise declining head-final order, no trace of which can be found in Romance BE-periphrases.

\section{References}

Adams, James (1991). 'Some Neglected Evidence for Latin habeo with Infinitive: the Order of the Constituents', Transactions of the Philological Society 89: 131-96.

Adams, James (1994). Wackernagel's Law and the Placement of the Copula esse in Classical Latin. Cambridge: Philological Society.

Adams, James (2013). Social Variation and the Latin language. Cambridge: Cambridge University Press.

Bourova, Viara (2005). 'A la recherche du 'conditionnel latin': les constructions 'infinitif + forme de habere' examinées à partir d'un corpus électronique', in C. Pusch, J. Kabatek and W. Raible (eds), Romanistische Korpuslinguistik: Korpora und diachrone Sprachwissenschaft, Tübingen: Narr, 303-16.

Bourova, Viara, and Liliane Tasmowski (2007). 'La préhistoire des futurs romans: ordre des constituants et sémantique', in L. de Saussure, J. Moeschler and G. Puskás (eds), Etudes sémantiques et pragmatiques sur le temps, l'aspect et la modalité (= Cahiers Chronos 19). Amsterdam: Rodopi, 25-41. 
Cardinaletti, Anna, and Michal Starke (1999). 'The Typology of Structural Deficiency: a Case Study of the three Grammatical Classes', in H. van Riemsdijk (ed.), Clitics in the languages of Europe. Berlin: Mouton de Gruyter, 145-233.

Cennamo, Michela (2001). 'On the Reorganization of Voice Distinctions and Grammatical Relations in Late Latin', in C. Moussy, J. Dangel, M. Fruyt, L. Sznajder and L. Nadjo (eds), De lingua latina novae quaestiones. Louvain-la-Neuve: Peeters, 51-65.

Cennamo, Michela (2005). 'Passive Auxiliaries in Late Latin', in: Kiss, S., L. Mondin and G. Salvi (eds), Latin et langues romanes: études de linguistique offertes à József Herman à l'occasion de son 80ème anniversaire. Tübingen: Niemeyer, 177-94.

Cinque, Guglielmo (1999). Adverbs and Functional Heads: a Cross-linguistic Perspective. Oxford: Oxford University Press.

Clackson, James, and Geoffrey Horrocks (2007). The Blackwell History of the Latin Language. Oxford: Blackwell.

Clancy, Patricia (1975). 'The rise of the synthetic future tense in Romance: a critique of some recent hypotheses (Benveniste, Valesio, Butler)', Romance Philology 28: 545-54.

Coleman, Robert (1971). 'The origin and development of Latin habeo + infinitive', Classical Quarterly n.s. 21, 215-32.

Coleman, Robert (1976). 'Further Observations on habeo + Infinitive as an Exponent of Futurity', Classical Quarterly n.s. 26: 151-9.

Danckaert, Lieven (2012). Latin Embedded Clauses: the Left Periphery. Amsterdam: Benjamins.

Danckaert, Lieven (2014). 'The Derivation of Classical Latin Aux-final Clauses: Implications for the Internal Structure of the Verb Phrase', in K. Lahousse and S. Marzo (eds), Romance Languages and Linguistic Theory 2012. Amsterdam: Benjamins, 141-59.

Danckaert, Lieven (2015). Assessing Phonological Correlates of Syntactic Change: the Case of Late Latin BE-periphrases. Ms. Ghent University.

Danckaert, Lieven (2016). 'Variation and Change in Latin BE-periphrases: Empirical and Methodological Considerations', in J. Adams and N. Vincent (eds), Early and Late Latin: Continuity or Change?. Cambridge: Cambridge University Press, 132-62.

Danckaert, Lieven (2017). The Development of Latin Clause Structure: A Study of the Extended Verb Phrase. Oxford: Oxford University Press.

Danckaert, Lieven (to appear). 'The Decline of Latin VOAux: Neg-incorporation and Syntactic Reanalysis', in A. Martins and A. Cardoso (eds), Word Order Change. Oxford: Oxford University Press.

de Melo, Wolfgang (2012). 'Kuryłowicz's first 'Law of Analogy' and the Development of Passive Periphrases in Latin', in P. Probert and A. Willi (eds), Laws and Rules in IndoEuropean. Oxford: Oxford University Press, 83-101.

Duarte, Inês, and Gabriela Matos (2000). 'Romance Clitics and the Minimalist Program', in J. Costa (ed.), Portuguese Synta Oxford: Oxford University Press, 116-42.

Embick, David (2000). 'Features, Syntax and Categories in the Latin Perfect', Linguistic Inquiry 31: 185-230.

Flobert, Pierre (1975). Les verbes déponents latins des origines à Charlemagne. Paris: Les Belles Lettres.

Gianollo, Chiara (2010). 'I verbi deponenti latini e l'unità della flessione in -r', in Incontri Triestini di Filologia Classica VIII (2008-2009). Trieste: Edizioni Università di Trieste, 23-49.

Halpern, Aaron, and Josip Fontana (1994). ' $\mathrm{X}^{\circ}$ and $\mathrm{X}^{\mathrm{max}}$ Clitics', West Coast Conference in Formal Linguistics 12: 251-66.

Harris, Martin (1978). The Evolution of French Syntax: a Comparative Approach. London: Longman. 
Haverling, Gerd (2008). 'On the Development of Actionality, Tense and Viewpoint from Early to Late Latin', in F. Josephson and I. Söhrman (eds), Interdependence of Diachronic and Synchronic Analyses. Amsterdam: Benjamins, 73-104.

Haverling, Gerd (2010). 'Actionality, Tense and Viewpoint', in P. Baldi and P. Cuzzolin (eds), New Perspectives on Historical Latin Syntax: vol. 2: Constituent Syntax: Adverbial Phrases, Adverbs, Mood, Tense. Berlin: Mouton de Gruyter, 277-523.

Herman, József (2002). 'La disparition du passif synthétique latin: nouvel essai sur l'écrit et le parlé en latin mérovingien', Estudis romànics 24: 31-46.

Hewson, John (1997). 'From Latin to Modern Romance', in J. Hewson and V. Bubeník (eds), Tense and Aspect in Indo-European languages. Amsterdam: Benjamins, 314-30.

Hyde, Brett (2011). 'Extrametricality and Non-finality', in M. van Oostendorp, C. Ewen, E. Hume and K. Rice (eds), The Blackwell Companion to Phonology. Oxford: WileyBlackwell, 1027-51.

Kühner, Raphael, and Karl Stegmann (1966²). Ausführliche Grammatik der lateinischen Sprache. Hannover: Hahn.

Ledgeway, Adam ([1997] 1999). 'I tempi sovraccomposti nel napoletano antico', L'Italia dialettale 60: 105-24.

Ledgeway, Adam (2012). From Latin to Romance: Morphosyntactic Typology and Change. Oxford: Oxford University Press.

Lema, José, and María-Luisa Rivero (1989). 'Types of verbal movement in Old Spanish: modals, futures and perfects', Probus 3: 237-78.

Leumann, Manu (1921). 'Part. perf. pass. mit fui im späteren Latein', Glotta 11: 192-4.

Muller, Henri François (1924). 'The Passive Voice in Vulgar Latin', The Romanic Review 15: 68-93.

Nespor, Marina, and Irene Vogel ([1986] 2007²). Prosodic Phonology (with a New Foreword). Berlin: Mouton de Gruyter.

Pezzini, Giuseppe (2011). 'Contraction of est in Latin', Transactions of the Philological Society $109: 327-43$.

Pinkster, Harm (1985). 'The Development of Future Tense Auxiliaries in Latin', Glotta 63: 186-208.

Roberts, Ian (1992). 'A Formal Account of Grammaticalisation in the History of Romance Futures', Folia Linguistica Historica 13: 219-58.

Rohlfs, Gerhard (1922). 'Das romanische habeo-Futurum und Konditionalis, Archivum Romanicum 6: 105-52.

Selkirk, Elizabeth (1980). 'Prosodic Domains in Phonology: Sanskrit Revisited', in M. Aronoff and M.-L. Kean (eds), Juncture: a Collection of Original Papers. Saratoga (Cal.), Anma Libri, 107-29.

Selkirk, Elizabeth (1984). Phonology and Syntax: the Relation between Sound and Structure. Cambridge (Mass.): MIT Press.

Starke, Michal (2014). 'Towards Elegant Parameters: Language Variation Reduces to the Size of Lexically-stored Trees', in C. Picallo (ed.), Linguistic Variation in the Minimalist Framework. Oxford: Oxford University Press, 140-52.

Stimm, Helmut (1977). 'Ein neuer früher Beleg des synthetischen Futurs', in H. Laitenberger, (ed.), Festgabe für Julius Wilhelm zum 80. Geburtstag. Wiesbaden: Steiner, 40-52.

Telve, Stefano (2005). 'Sul trapassato remoto: valori sintattici, aspettuali e semantici dei tipi fui stato e fui stato amato in italiano antico e moderno', Lingua e Stile 40: 263-94.

Thielmann, Philipp (1885). 'Habere mit dem Infinitiv und die Enstehung des romanischen Futurums', Archiv für lateinische Lexikographie und Grammatik 2: 48-89; 157-202.

Valesio, Paolo (1968). 'The Romance Synthetic Future Pattern and its first Attestations', Lingua 20: 113-61; 279-306. 
Valesio, Paolo (1970). 'The Synthetic Future again: Phonology and Morpho-syntax', Lingua 24: 181-93.

Väänänen, Veikko $\left(1981^{3}\right)$. Introduction au latin vulgaire. Paris: Klincksieck.

Winters, Margaret (1984). 'Steps toward the Romance Passive inferrable from the Itinerarium Egeriae', Romance Philology 37: 445-54.

Zanuttini, Raffaella (1997). Negation and Clausal Structure: a Comparative Study of Romance Languages. Oxford: Oxford University Press. 